\title{
THE CHANGING INTERNATIONAL DIVISION OF LABOR AND REGIONAL EMPLOYMENT CYCLES IN THE U.S.
}

\author{
Harvey A. Goldstein*
}

\section{Introduction}

Changes in the international division of labor (IDOL) in the past 15 to 20 years have led to profound changes in the structure and performance of the advanced economies. In the United States, a 25 year period of sustained economic growth gave way in about 1970 to a period of stagflation and often painful structural change. Traditional industries suffered steep declines. Flows of capital investment out of the United States accelerated while the potential jobs were lost first to Europeans and then to third world countries. U.S. industries were faced with increased import penetration, direct foreign investment increased, and new types of structural employment and labor market mismatches became imbedded in the U.S. economic structure (Muller, 1980).

The economic conditions of the same period can also be characterized as a series of increasingly stronger international and national business cycles. Indeed, it is difficult to separate the origins of the structural changes mentioned above from the causes of the strong cyclical fluctuations in the period throughout the advanced economies. Glickman (1980) has noted, for instance, that the increased internationalization of the advanced economies may have exacerbated the severity of the U.S. cyclical fluctuations. That is, a greater proportion of international trade has led to greater synchronization of the national business cycles among major trading partners.

Analyses of the hypothetical links among changes in the IDOL, structural changes in the domestic economy, and cyclical behavior at the level of the national economy, however, hide important interregional variations in the level of economic well-being, secular economic growth trends, and cyclical behavior. There is no doubt

*Associate Professor of City and Regional Planning, University of North Carolina, Chapel Hill. The author wishes to thank Edward M. Bergman, Michael I. Luger, and Norman J. Glickman for helpful comments on an earlier draft. that the U.S. economy as a whole has become dramatically more open to the international economy, and hence more sensitive to changes in its structure and to its cyclical fluctuations. Yet because the increase in the openess of the U.S. economy is not evenly shared among regions, we should expect uneven regional sensitivity to structural changes and to cyclical fluctuations in the international economy (Glickman, 1980, 1985; Renaud, 1984).

In this paper we explore at an empirical level some of the effects of changes in the IDOL on the cyclical behavior of the largest U.S. metropolitan regions. Previous research on the determinants of regional cyclical behavior (Borts, 1960; King et al, 1972; Browne, 1978; Victor and Vernez, 1981; Howland, 1984) has ignored the effects of international economic variables. Recent research on the regional effects of the internationalization of the U.S. economy (Hansen, 1979; U.S. Department of Housing and Urban Development, 1979; Cohen, 1981; Noyelle, 1983; Renaud, 1984) has tended to focus on induced changes in regional industry structure but has virtually ignored effects on regional cyclical performance.

Two types of effects are hypothesized. The first type is an indirect one. It is transmitted through induced changes in the industrial and enterprise structure of a regional economy. That is, changes in the IDOL have hypothetically led to uneven decline and growth of product markets of U.S. domestic industries, which in turn has led to a spatial reallocation of industrial capital and employment. The spatial reallocation of capital is an ongoing attribute of the process of capitalist development, yet there is substantial evidence that this process accelerated during the 1970 s as the result of changes in the structure of the international economy (Bluestone and Harrison, 1982). Since a region's cyclical behavior is a composite of the cyclical fluctations of each of its constituent industries (plus that due to interaction), we would expect that changes in regional industry structure should lead to changes in a regional economy's cyclical behavior and per- 
formance.

The second type of hypothesized regional cyclical effect of changes in the IDOL is a direct one. The internationalization of the U.S. economy renders regional economies, on average, less immune to the effects of cyclical fluctuations in the level, direction, and pattern of international trade, as well as fluctuations in international capital flow and commodity prices. We expect substantial variation, however, in the sensitivity of U.S. metropolitan regions to cyclical fluctuations in the international economy. There are several reasons for the expectation: (1) interregional differences in the importance of foreign export markets for locally produced goods and services; (2) interregional differences in local producers' domestic markets' vulnerability to foreign imports; and (3) regional differences in relative productivity and production cost advantages in comparison to foreign production locations.

In the remainder of this paper we present the results of empirical analyses which attempt to provide, tempered by data availability, at least partial evidence of the magnitude of these two types of effects of changes in the IDOL on the cyclical behavior of U.S. metropolitan regions. First, we provide descriptive measures of the variation of cyclical severity among U.S. metropolitan regions and of the change in the amount of interregional variation over time. Second, we analyze the relationship between recent changes in regional industry composition and regional cyclical severity to explore the indirect effects of changes in the IDOL on regional cyclical behavior. The third part of the analysis provides estimates of the sensitivity of U.S. metropolitan regions to a measure of cyclical fluctuations in international economic activity, and discusses the interregional differences in the estimated magnitude of the sensitivity. The final section of the paper is a brief discussion of some policy implications of the results of the three parts of the analysis as a whole, and of suggested extensions to the present analysis.

\section{The Variation in Regional Cyclical Behavior}

The cycle severity of 50 of the largest U.S. metropolitan regions was measured for each of three major recessions over the 1970-1983 period. ${ }^{1,2}$ The unit of measurement was the level of total nonagricultural employment (or manufacturing employment) using monthly seasonally adjusted, U.S. Bureau of Labor Statistics Employment and Earnings data. Cycle severity is defined here as percent decline in regional employment between the regional peak and the succeeding trough of the contraction phase of each regional cycle. In cases where a particular region did not experience any employment decline, the cycle severity was defined as zero.

The calculated measures of cycle severity for total nonagricultural employment and manufacturing employment in each of the 50 metropolitan regions, for each of the three major post-1970 national recessions, are shown in Table 1. The unweighted means, standard deviations, and coefficients of variation (CV) were calculated for the sample of 50 regions. The summary statistics show what is already common knowledge-that each of the three recessions was progressively more severe (data on return-to-peak duration, not included here, show that each recession was progressively longer as well). But the summary statistics also show an interruption, and potentially the beginning of a reversal, in the half-century trend of convergence of severity of regional business cycles (Victor and Vernez, 1981).

The interregional variation in the severity of the cyclical downturn of the manufacturing sector is smaller compared to total nonagricultural employment, as evidenced by the coefficient of variation, and as would be expected. This also verifies the notion that a region's manufacturing sector generally is still its primary window through which exogenous regional, national, and international fluctuations in product demand and prices of non-local factor inputs are transmitted to the regional economy as a whole. This continues despite the growth of importance of producer services as an export product in a few of the largest metropolitan regions (Noyelle and Stanback, 1983). Conversely, the size and nature of a region's nonmanufacturing sectors tend to determine the extent to which a cyclical contraction centered in the manufacturing sector is buffered in the regional economy as a whole. The figures in Table 1 suggest that the effectiveness of the nonmanufacturing sectors' classic buffer role now varies considerably, at least among the metropolitan regions in the sample.

The reasons for the possible reversal of the 
TABLE 1

Regional Cycle Severity for Three Post-1970 Recessions

\begin{tabular}{|c|c|c|c|c|c|c|}
\hline \multirow[b]{2}{*}{ Area } & \multicolumn{3}{|c|}{$\begin{array}{c}\text { Total Nonagricultural Employment } \\
\text { Cycle Severity }\end{array}$} & \multicolumn{3}{|c|}{$\begin{array}{l}\text { Manufacturing } \\
\text { Cycle Severity }\end{array}$} \\
\hline & $1970-71$ & $1974-76$ & $1980-83$ & $1970-71$ & $1974-76$ & $1980-83$ \\
\hline Albany & 0.8 & 2.7 & 3.8 & 7.9 & 12.5 & 22.1 \\
\hline Anaheim & 1.3 & 3.2 & 4.1 & 7.9 & 8.9 & 6.5 \\
\hline Atlanta & - & 6.4 & - & 9.5 & 17.1 & 7.2 \\
\hline Austin & - & - & 1.3 & - & 4.3 & 1.8 \\
\hline Baltimore & 0.6 & 3.2 & 5.0 & 12.4 & 14.1 & 19.9 \\
\hline Birmingham & 1.7 & 2.0 & 8.4 & 5.7 & 12.7 & 33.7 \\
\hline Boston & 2.8 & 4.2 & 2.0 & 11.2 & 11.5 & 6.3 \\
\hline Buffalo & 6.0 & 4.6 & 11.7 & 16.8 & 14.8 & 31.0 \\
\hline Charlotte & - & 7.3 & 2.8 & 2.8 & 15.3 & 6.2 \\
\hline Chicago & 2.9 & 5.0 & 6.6 & 9.8 & 15.1 & 25.2 \\
\hline Cincinnati & 2.3 & 3.1 & 6.8 & 12.4 & 9.1 & 17.6 \\
\hline Cleveland & 5.8 & 4.1 & 10.3 & 13.8 & 12.0 & 24.7 \\
\hline Columbus & - & 4.1 & 3.8 & 7.0 & 13.8 & 17.0 \\
\hline Dallas & 3.0 & 2.5 & - & 17.8 & 7.8 & 7.5 \\
\hline Dayton & 8.2 & 5.7 & 9.2 & 21.7 & 16.7 & 26.7 \\
\hline Denver & - & 2.2 & 1.5 & 2.0 & 9.9 & 7.0 \\
\hline Detroit & 7.5 & 7.7 & 16.2 & 19.2 & 20.0 & 35.6 \\
\hline Flint & 10.2 & 13.2 & 19.9 & 16.6 & 27.1 & 37.9 \\
\hline Greensboro & 1.0 & 6.3 & 3.8 & 3.0 & 10.8 & 7.2 \\
\hline Hartford & 4.4 & 2.2 & 1.2 & 26.7 & 11.2 & 14.2 \\
\hline Houston & 0.4 & - & 6.9 & 2.8 & - & 29.7 \\
\hline Indianapolis & 2.7 & 3.8 & 7.5 & 10.8 & 12.2 & 21.3 \\
\hline Jacksonville & 1.2 & 2.5 & - & 3.4 & 9.5 & 10.3 \\
\hline Kansas City & 3.2 & 3.0 & 8.4 & 11.2 & 14.0 & 18.3 \\
\hline Los Angeles & 4.7 & 3.1 & 3.5 & 13.6 & 8.7 & 9.5 \\
\hline Louisville & 3.2 & 6.4 & 10.8 & 13.1 & 18.0 & 28.8 \\
\hline Memphis & 1.9 & 4.6 & 6.6 & 7.2 & 16.4 & 20.1 \\
\hline Miami & 1.5 & 7.1 & 3.3 & 7.1 & 15.8 & 8.0 \\
\hline Milwaukee & 3.6 & 4.1 & 11.7 & 10.4 & 9.9 & 30.4 \\
\hline Minneapolis & 4.4 & 3.1 & 4.4 & 14.7 & 11.8 & 10.4 \\
\hline Nassau-Suffolk & 0.9 & 2.3 & - & 13.3 & 8.5 & 2.4 \\
\hline New Orleans & 0.8 & 0.3 & 4.2 & 3.0 & 9.5 & 28.3 \\
\hline New York & 5.5 & 9.9 & 1.3 & 16.7 & 19.9 & 13.3 \\
\hline Newark & 1.9 & 4.5 & 1.6 & 9.6 & 10.9 & 13.5 \\
\hline Norfolk & 1.0 & 3.8 & 1.4 & 2.2 & 14.5 & 18.0 \\
\hline Omaha & - & 2.3 & 6.0 & 7.6 & 21.9 & 18.1 \\
\hline Orlando & - & 10.8 & - & 7.9 & 18.2 & 6.2 \\
\hline Philadelphia & 3.4 & 4.1 & 2.8 & 11.9 & 13.5 & 15.6 \\
\hline Phoenix & 0.8 & 6.6 & 1.1 & 12.6 & 17.8 & 9.2 \\
\hline Pittsburgh & 3.5 & 1.1 & 12.3 & 13.0 & 8.8 & 36.3 \\
\hline Portland & 1.7 & 3.2 & 10.7 & 8.1 & 13.0 & 22.0 \\
\hline Raleigh/Durham & - & 3.0 & 1.7 & 1.7 & 9.3 & 2.2 \\
\hline Rochester & 2.9 & 3.8 & 4.3 & 8.9 & 8.6 & 10.6 \\
\hline St. Louis & 2.5 & 4.1 & 6.2 & 9.4 & 15.7 & 20.7 \\
\hline San Antonio & - & 2.5 & 1.3 & 9.1 & 10.7 & 9.0 \\
\hline San Diego & - & - & 1.8 & 8.8 & 9.8 & 6.4 \\
\hline San Francisco & 2.5 & 1.0 & 2.6 & 11.9 & 8.4 & 13.2 \\
\hline San Jose & 2.7 & 4.2 & 1.9 & 8.9 & 10.4 & 5.8 \\
\hline Tulsa & 1.8 & 0.7 & 6.0 & 11.6 & 1.7 & 23.1 \\
\hline Youngstown & 6.5 & 9.5 & 17.2 & 14.5 & 20.5 & 40.5 \\
\hline Mean & $3.0 \%$ & $4.4 \%$ & $5.9 \%$ & $10.4 \%$ & $12.9 \%$ & $17.1 \%$ \\
\hline Std. dev. & 2.2 & 2.7 & 4.6 & 5.3 & 4.7 & 10.4 \\
\hline CV & 72.9 & 61.0 & 77.9 & 50.7 & 36.4 & 61.1 \\
\hline
\end{tabular}

Note: Cycle severity measured as percent decline from peak to trough. 
long trend of regional cyclical convergence can only be speculated upon at this time. The trend toward convergence was brought about by at least three principal factors: (1) convergence of regional industrial $\mathrm{mix}$, i.e, less regional specialization; (2) a half century of relatively strong, central, government-directed (Keynesian) economic policy; and (3) a higher degree of national economic integration through increasing concentration of control and ownership of capital. If the convergence trend is reversing as a result of the weakening of these three factors, then changes in the structure of the international economy may be at least indirectly complicit. Industrial restructuring in the United States brought about through sectoral rationalization on a global basis, as well as changes in relative factor input prices and realignment of product markets on an international scale, have certainly had uneven regional incidence in the United States. The uneveness of these effects has contributed to the recent divergence of both regional growth trends and industry mix.

Second, recent and proposed Reagan administration changes in national economic policy and the implicit national industrial policy, in part a reaction to loss of American business competitiveness in world markets, have been shown to lead in the direction of greater uneven regional development (Luger, 1983; Glickman and Van Wagner, 1984).

Finally, reversals in the centralization of corporate organization and strategy toward greater regional decentralization and autonomy may be contributing to tendencies toward spatial disintegration of the national economy. The link back to change in the IDOL is less obvious for this factor. On the other hand a relatively new factor, the increased but uneven degree of openness of regional economies to the international economy, is hypothesized in this paper to be partially responsible for divergence of regional cyclical behavior. This is analyzed below.

\section{Relationships Between Recent Changes in Regional Industry Composition and Cyclical Behavior}

A long tradition of research on regional business cycles has consistently held that the larger the regional concentration in manufacturing, particularly durable goods, the more cyclically sensitive and less cyclically stable is the region (e.g., Vining, 1946; Borts, 1960; Victor and Vernez, 1981). Conversely, those regions which have experienced growth in the concentration of services; finance, insurance and real estate (FIRE); and trade would be considered to be less cyclically sensitive and more stable as a result. These findings are consistent with a closely related set of recent studies which found strong relationships between regional industrial diversification and economic stability (Conroy, 1975; Kort, 1981).

We have analyzed two sets of hypothesized relationships. The first set is between regional concentration in manufacturing and FIRE, respectively, and regional cycle severity in each of the 1970-1971, 1974-1976, and 1980-1983 cycles. $^{3}$ The second set is between changes in the regional concentration of manufacturing and FIRE employment preceding the 1980-1983 recession, and the regional severity of that recession. The results are shown in Table 2.

The commonly-held relationship between a region's concentration in manufacturing employment and cyclical severity is supported by the results here. The correlation coefficients are positive and significant.

The relationship between a region's concentration in FIRE employment and cycle severity is less clear. Concentration in FIRE employment is not significantly correlated with any of the respective measures of cycle severity.

The more interesting questions, however, are to what degree are changes in the concentration of manufacturing employment related to regional cycle severity? We might expect that those regions which suffered the heaviest losses in manufacturing employment during the first half of the 1970-1983 period, including the 1970-1971 and 1974-1976 recessions, would be "leaner and more fit" with a stronger pool of firms to face the subsequent 1980-1983 cyclical recessions more successfully. Correlation coefficients were calculated between change in regional concentration in manufacturing employment from January 1970 and August 1975, and several measures of 1980-1983 cycle severity: 1) the (usual) percent decline in total employment between peak and trough; 2) the region's rank in cycle severity relative to other regions in the sample; and 3) the region's improvement in cyclical performance measured as the difference be- 
Table 2

Correlations Between Regional Industry Composition and Change, and Regional Cyclical Behavior

Variables

Percent manufacturing employment and: 1970 cycle severity 1974 cycle severity 1980 cycle severity

Percent FIRE employment and: 1970 cycle severity 1974 cycle severity 1980 cycle severity
Pearson Correlation Coefficient

$0.60 * *$

$0.37 * *$

$0.56 * *$

$-0.17$

$-0.16$

$-0.12$

Change in percent manufacturing employment (1/70-8/75) and: 1980 cycle severity

Rank in magnitude of 1980 cycle severity 1980 cycle severity minus 1974 cycle severity

Change in percent FIRE employment (1/70-12/78) and: 1980 cycle severity

Rank in magnitude of 1980 cycle severity 1980 cycle severity minus 1974 cycle severity

$(\mathrm{N}=50)$

* Significant at .05

**Significant at .01

tween the 1980-1983 cycle severity and the 1974-1976 cycle severity (refer to Table 2). The results support the hypothesis that the greater the loss of concentration of manufacturing through the first two cycles of the 1970s, the less severe the 1980-1983 downturn and the larger the improvement in cyclical performance in 1980-1983 from the 1974-1976 downturn.

The hypothesis of a negative relationship between gain in a region's concentration in FIRE employment and cycle severity, however, was not supported by the results. This differs from the results obtained by Victor and Vernez (1981) over an earlier period. Concentration in FIRE employment is now becoming so ubiquitous among both declining and growing regions that regional growth in that sector may no longer represent a sure-fire prescription for improved cyclical stabiliy. ${ }^{4}$

A region's relative gain or loss in the concentration of manufacturing and producer services during the last 15 years cannot all be attributed to changes in the IDOL. For example, important changes in the regional division of labor within the United States have resulted from the spatial and sectoral biases of federal tax and spending policies, as well as placetargeted urban and regional policies (Glickman, 1984). We have not attempted to isolate the effect of the changing IDOL on regional in- dustrial composition in this paper. Yet the results provide support for the notion that the loss of concentration in manufacturing and the gain in services, particularly producer services in U. S. metropolitan regions, in general reflecting changes in the IDOL, are altering regional cyclical behavior. The effects of the loss of concentration of manufacturing employment so far seem to be leading to increased cyclical stability, albeit at a high price. But on the other hand, as the rate of technological change in the production of services increases, it is not out of the question for one to see the incidence of a negative relationship between regional concentration in the services sector and cyclical stability.

\section{The Sensitivity of U. S. Metropolitan Regions to Cyclical Fluctuations in the International Economy}

The internationalization of the U.S. economy implies that, on average, regional economies will be more "open" to fluctuations in the international economy. Yet we expect that there will be substantial variation around the average increase in the effect of fluctuations in the international economy on regional economies in the United States. That is because regional economies vary in such factors as their accessibility to foreign markets, their in- 
dustry mix's vulnerability to import penetration, and their relative productivity and production cost advantages compared to foreign production locations.

In attempting to estimate the sensitivity of U.S. metropolitan regions to international economic fluctuations, however, there is no single, all-inclusive measure of international economic activity in consistent monthly or quarterly time-series. We utilize the fluctuations in the monthly index of production of OECD countries (excluding the United States) as a proxy for fluctuations in international economic activity. ${ }^{5}$ This measure is imperfect because it is non-neutral with respect to the geographical specialization of international trade and other economic linkages among U.S. metropolitan regions. For instance, trade with Mexico has an enormous impact on the economies of Southwestern states, but these impacts are not taken into account with these data. Also, because any appropriate measure of international economic activity is bound to be significantly correlated with the level of U.S. economic activity, it is necessary to control for the latter. Only a portion of the full effect of international economic fluctuations on regional cyclical behavior can be estimated within the framework of single-equation regression models, as discussed below. Some suggestions for dealing with these problems in subsequent work are made in the last section of this paper.

\section{The Estimated Model}

A multiple regression model was calibrated with monthly time-series data (1970-1983) to estimate each region's sensitivity to fluctuations in the index of production of OECD countries (excluding the United States), controlling for the effect of cyclical fluctuations in the national economy.

The model uses a polynominal, distributed lag formulation for the index of production variable. ${ }^{6}$ The specification of the regression equation is:

(1) $\mathrm{E}_{\mathrm{t}}=\alpha+\beta_{1} \mathrm{D}_{1} \mathrm{US}_{\mathrm{t}+m}+\beta_{2} \mathrm{D}_{2} \mathrm{US}_{\mathrm{t}+n}+\beta 3$

where $\quad\left(\sum_{t=-6}^{+6} w_{t+p} \cdot I P E_{t+p}\right)+u_{t}$

$\mathrm{E}_{\mathrm{t}}$ is the regional total employment monthly growth rate between $t-1$ and $t$.
$\mathrm{US}_{\mathrm{t}}$ is the national total employment monthly growth rate between $t-1$ and $t$.

$D_{1}$ is a dummy variable such that

$$
\mathrm{D}_{1}=1 \text { if } \mathrm{US}_{\mathrm{t}+\mathrm{m}} \geq 0
$$

$\mathrm{D}_{2}$ is a dummy variable such that

$$
\begin{gathered}
\mathrm{D}_{2}=1 \text { if } \mathrm{US}_{\mathrm{t}+\mathrm{n}}<0 \\
0 \text { otherwise }
\end{gathered}
$$

$\mathrm{IPE}_{t}$ is the monthly rate of change of the index of OECD production, excluding the United States, between $t-1$ and $t$.

$m, n$, and $p$ are leads $(+)$ or lags $(-)$ in months of the dependent variable relative to the respective independent variable. The allowable values range from -6 to +6 .

$\alpha, \beta_{1}, \beta_{2}, \beta_{3}$ are regression parameters to be estimated as $a_{1}, b_{1}, b_{2}$ and $b_{3}$, respectively. $b_{3}$ is the sum of the estimated lagged coefficients.

$w_{t}$ are lag weights fitted to a third order polynomial function.

$u_{t}$ is the error term. ${ }^{7}$

The model in (1) is an extension of the general form used by King et al (1972), Vernez et al (1977), Victor and Vernez (1977), and Bergman and Goldstein (1983). The specification of the model yields readily interpretable and policy relevant parameters. $b_{1}$ and $b_{2}$ are estimates of a region's sensitivity, or responsiveness, to expansions and contractions, respectively, in the national economy. Thus, if $b_{1}$ $=2.0$, for each 1 percent increase in national employment during an expansion, the region's employment base expands 2 percent. If $b_{2}=$ 2.0 , for each 1 percent decline in national employment during a recession, the region's employment base contracts 2 percent. The closer $b_{1}$ and $b_{2}$ are to 1.0 , the more the region's cyclical amplitude resembles the national average. A region with estimated sensitivity coefficients statistically equal to zero implies that the cyclical fluctuations of the regional economy are independent of national expansion and contraction phases of business and growth cycles.

$b_{3}$, the sum of the lagged coefficients for IPE, is a measure of the sensitivity of a given regional economy to fluctuations in the index of OECD nations' production. Similar to $b_{1}$ and $b_{2}$, the magnitude of the coefficient indicates the percent change in regional employment for every 1 percent change in the index of production. Since the effects of national employment 
fluctuations are controlled for, $b_{3}$ measures the regional sensitivity to fluctuations in the level of OECD country production above and beyond that which first affects the level of national employment on average. As such, the measure used here systematically underestimates regional sensitivity to international economic fluctuations since a portion of the impact of those fluctuations is transmitted indirectly to regional economies through their effects on the U.S. economy as a whole. ${ }^{8}$

\section{Results of the Estimated Models}

We focus here on the analysis of estimated values of $b_{3}$, the regional sensitivity to fluctuation in the level of OECD production, although the interregional variation in sensitivity coefficients to expansions and contractions of the national economy have substantive and policyrelevant importance as well. ${ }^{9}$

There is indeed large interregional variation in the magnitude of the estimated sensitivity of regional economies to fluctuations in the international (OECD) economy (see the Appendix table for the estimates of the sensitivity coefficients from (1) for eàch area). ${ }^{10}$ The median value of $b_{\text {IPE }}$ is 0.150 but the range (in absolute value) is from 0.029 to 0.815 . As an example, the magnitude of $\mathrm{b}_{\text {IPE }}$ for Pheonix,
Arizona is interpreted as a 0.815 percent change in total regional employment (distributed over 13 monthly periods) for every one percent change in the index of production for the OECD countries, controlling for national employment fluctuations. Seven regions had negative coefficients although only one of these (Flint, Michigan) was statistically significant.

The metropolitan regions with the largest estimated sensitivity to fluctuations in the international economy are all rapidly growing sun-belt areas (see Table 3). Many have emerged as regional service and market centers within the changing U.S. system of cities. Taken as a whole, their manufacturing bases are more oriented to high-technology industries than average, although the relative size of the manufacturing sector within each region varies considerably. The average age of capital is younger, while production costs, and particularly labor costs, are lower than the U.S. metropolitan average. Many of these areas, although not all, had well above average proportions of foreign-export related manufacturing production (U.S. Department of Commerce, 1981). Also, their economies tend to be more independent of cyclical fluctuations in the national economy compared to the metropolitan average.

Table 3

Fifteen Metropolitan Regions with the Largest Estimated Sensitivity to International Economic Fluctuations

Region $\quad$ b $_{\text {IPE }}{ }^{\text {a }}$

1. Phoenix, AZ

0.815

2. Orlando, FL

0.690

3. San Jose, CA

0.589

4. Anaheim, CA

0.516

5. Denver, CO

0.477

6. Charlotte, NC

0.436

7. Miami, FL

8. Dallas, TX

0.390

0.383

9. Portland, OR

0.371

10. Atlanta, GA

0.340

11. Raleigh-Durham, NC

0.327

12. Memphis, $\mathrm{TN}$

0.317

13. San Antonio, TX

0.313

14. Austin, TX

15. Minnespolis, MN

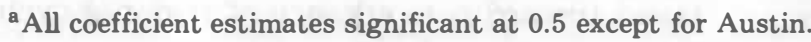


Noticeably missing from the set of regions with the highest sensitivity coefficients are the older manufacturing regions in the North, as well as the designated national/international service centers which include New York, Chicago, Los Angeles, and San Francisco (Noyelle and Stanback, 1983). One might expect that the older manufacturing regions would be sensitive to fluctuations of economic activity in the OECD countries because of increasing import penetration of U.S. domestic markets by goods produced both in OECD countries and in the U.S. sunbelt regions. Also, many of the areas in the North Central states have traditionally relied on exports of heavy machinery, fabricated metal products, and some types of transportation equipment to OECD countries.

There are several plausible and compatible reasons for the low IPE sensitivity coefficients in older manufacturing regions such as Baltimore, Philadelphia, Pittsburgh, Cleveland, Detroit, and Milwaukee. First, industry diversification toward services and retail trade starting prior to the study period has lowered the relative importance of the durable goods sectors within the respective regions. Second, much of the "diversification" has been forced through long-term secular declines in investment and employment in the respective durable goods manufacturing sectors. These secular declines have not been necessarily in close conformance with international (OECD) business cycles. Third, in these regions a relatively larger portion of the effect of international economic fluctuations is probably transmitted through the average effect on the U.S. economy as a whole and thus is absorbed in $b_{1}$ and $b_{2}$. That is, the dominant industrial sectors within these older mnaufacturing regions most sensitive to international economic fluctuations are also likely to be the sectors whose fluctuations are most highly correlated with cyclical fluctuations in the U.S. economy as a whole.

We account for the low sensitivity of national/ international service centers to fluctuations in the OECD IPE by the fact that the economies of these regions are linked more closely to the international economy through the producer services sectors than goods production activities within their respective regions. While ultimately these regions' producer services sectors will expand or contract as a function of the volume and pattern of international trade of manufactured goods, the respective producer service sectors heretofore have been relatively insensitive to fluctuations in the amount of manufacturing activity in OECD countries. Thus part of the explanation for the lower than expected sensitivity coefficients for these four regions is the imperfection of the proxy for level of overall international economic activity. A measure of fluctuations in international economic activity that includes, say, the value of the dollar vis a vis other currencies may be a more appropriate variable for regions with large concentrations of producer services. Also, Los Angeles and San Francisco would be expected to be relatively more sensitive to fluctuations in economic activity in Asia and perhaps Latin America than in western Europe. On the other hand, we cannot falsify, on the basis of observations to date, the popular theory that the export of producer services to the rest of the world may be a source of regional cyclical stability, despite greater vulnerability to stronger cyclical fluctuations from increased internationalization of the U.S. economy.

\section{Some Policy Implications of the Results and Suggestions for Further Research}

Previous research has suggested that changes in the IDOL have had important differential impacts on the structure and longterm performance of U.S. metropolitan regions. Results of the exploratory analyses described above suggest that regional restructuring (at least partially induced by changes in the IDOL, and the increased openness of U.S. metropolitan regions to international economic fluctuations) may be having important but differential effects on regional cyclical behavior. Indeed the growing internationalization of the U.S. economy may be leading to greater regional employment instability, ironically, in those regions which have been heretofore relatively insensitive to the strong cyclical swings of the U.S. economy during the 1970 s and early 1980s.

This international source of regional economic instability largely lies beyond the control of traditional national macroeconomic policy tools. Moreover, even a return to a political consensus for rational macroeconomic stabilization policies may not yield effective results if, indeed, there is a reversal of the trend toward convergence of regional cyclical 
behavior, in part caused by shifts in the IDOL. Put another way, a rising tide, in the form of higher levels of national economic growth from "successful" macroeconomic intervention, may raise all ships (regions), but it may raise them increasingly unevenly.

It may be reasonable to reopen the discussion of the feasibility of more flexible and customized regional-specific economic stability programs. The analytic problems, not to mention the political and legal impediments, are formidable. Policy-driven research to help predict the timing and severity of regional cycles, in order to improve the timing and effectiveness of federal public works and CETA programs as local countercyclical tools, yielded disappointing results a decade ago (Vernez et al., 1977). With the additional effect of international economic fluctuations on regional economies, the regional cycle prediction problem is likely to be even more difficult. Improved regional economic data and subnational indicators of international economic activity will be essential, however, to more closely monitor regional cycles and identify the various sources of cyclical instability. This analytic step is viewed as a prerequisite for designing regional policies whose objectives include economic stability.

A more flexible and regional-specific economic stabilization approach might well include microeconomic industrial policies designed and implemented at the regional level. Mainstream proponents consider industrial policies an essential element of a long-term economic growth strategy rather than part of an economic stabilization policy (Magaziner and Reich, 1982). Yet the recent intertwining of recurrent national business cycles and regional secular growth or decline trends suggests that much of the regional development problem should be considered a regional economic stabilization problem and vice versa (Bergman and Goldstein, 1983). This perspective may be as relevant for currently growing regions as for stagnant and declining regions. Indeed the recent cyclical performance in the growing regions has been poor as the ability for even large, oligopolistic firms in the United States to engage in labor hoarding strategies during economic downturns has eroded in the face of fierce competition from foreign producers with more rapidly increasing productivity rates.

For stagnant and declining regions, the ob- jectives of regional industrial policies might appropriately include the strengthening of the basic infrastructure of the region, and reattending to regional industrial diversification. These regional industrial policy objectives imply strategies for improving the underlying autonomous growth rate of a region, i.e., independent of national and international economic expansion and contractions. Thus, in contrast to regional industrial diversification strategies aiming to minimize the collective amplitude of a region's constituent industries (e.g., Conroy, 1974), the appropriate strategy might be diversification among industries at various stages of the product cycle. This was suggested by Thompson (1965) 20 years earlier, but in practice it has been ignored, perhaps as the result of the lure of attracting hightechnology manufacturing and producer services. Attention might also be given to diversification among types of enterprise organizations (e.g., single plant, branch plant, multinational corporation) and product market orientations within the regional economy. Our results at least suggest that industrial policies oriented exclusively to attracting producer services and high tech manufacturing are not necessarily good prescriptions for regional economic stability and thus long term regional economic development.

\section{Suggestions for Further Research}

The results reported here should be considered suggestive and exploratory rather than conclusive. Data availability, for instance, hampers more elaborate regression model specifications to control for the possible effects of other economic variables correlated with both IPE and regional employment fluctuations. Several extensions and refinements could be performed, however, within the constraints of present data.

First, the regression models could be calibrated for each half of the 1970-1983 period. This would provide some evidence of changes in the regional sensitivity to international economic fluctuations during a 13 year period in which a number of different phenomena were simulatenously occurring, including large swings in the value of the U.S. dollar. Certainly there was a higher degree of internationalization of the U.S. economy in 1983 than in 1970.

Second, measures of other aspects of interna- 
tional economic activity for which consistent time-series data exist could be included in the regression model to identify in finer detail the nature of each region's sensitivity to different aspects of international economic fluctuations. This could also alleviate the non-neutral geographic and sectoral bias of using OECD industrial production as the proxy for level of international economic activity.
Third, that portion of international economic fluctuations which is transmitted to regional economies through the U.S. national economy as a whole can be estimated with a recursive or simultaneous equation formulation. Several technical estimation problems caused by the presence of distributed lag variables, however, would first need to be resolved.

Appendix

Results of Estimation of Regional Sensitivity to Cyclical Fluctuations in the International Economy

\begin{tabular}{|c|c|c|c|c|c|c|}
\hline \multirow[t]{2}{*}{ Area } & \multicolumn{2}{|l|}{ USPOS } & \multicolumn{2}{|l|}{ USNEG } & \multirow{2}{*}{$\begin{array}{c}\text { IPE } \\
b_{3} \\
\text { (t-ratio) }\end{array}$} & \multirow[t]{2}{*}{$\mathrm{R}^{2}$} \\
\hline & $\begin{array}{c}b_{1} \\
\text { (t-ratio) }\end{array}$ & $\mathrm{m}$ & $\begin{array}{c}\mathrm{b}_{2} \\
\text { (t-ratio) }\end{array}$ & $\mathrm{n}$ & & \\
\hline Albany & $\begin{array}{c}0.58 \\
(4.80)\end{array}$ & -4 & $\begin{array}{c}0.79 \\
(3.93)\end{array}$ & 0 & $\begin{array}{r}-0.065 \\
(-0.71)\end{array}$ & .40 \\
\hline Anaheim & $\begin{array}{c}0.40 \\
(2.67)\end{array}$ & 0 & $\begin{array}{c}0.52 \\
(2.46)\end{array}$ & 1 & $\begin{array}{r}0.516 \\
(2.63)\end{array}$ & .85 \\
\hline Atlanta & $\begin{array}{c}0.89 \\
(6.06)\end{array}$ & 0 & $\begin{array}{c}0.67 \\
(2.97)\end{array}$ & 1 & $\begin{array}{l}0.340 \\
(2.60)\end{array}$ & .73 \\
\hline Austin & $\begin{array}{c}0.79 \\
(3.16)\end{array}$ & -4 & $\begin{array}{c}0.62 \\
(0.16)\end{array}$ & 2 & $\begin{array}{l}0.310 \\
(1.40)\end{array}$ & .31 \\
\hline Baltimore & $\begin{array}{c}0.56 \\
(4.11)\end{array}$ & 0 & $\begin{array}{c}0.63 \\
(2.91)\end{array}$ & 0 & $\begin{array}{l}0.051 \\
(0.47)\end{array}$ & .56 \\
\hline Birmingham & $\begin{array}{c}0.97 \\
(5.25)\end{array}$ & 0 & $\begin{array}{c}0.90 \\
(3.23)\end{array}$ & 0 & $\begin{array}{l}0.134 \\
(0.69)\end{array}$ & .69 \\
\hline Boston & $\begin{array}{c}0.43 \\
(3.23)\end{array}$ & -1 & $\begin{array}{c}1.04 \\
(5.01)\end{array}$ & 0 & $\begin{array}{l}0.029 \\
(0.26)\end{array}$ & .63 \\
\hline Buffalo & $\begin{array}{c}0.66 \\
(3.28)\end{array}$ & 0 & $\begin{array}{c}1.38 \\
(4.38)\end{array}$ & 0 & $\begin{array}{l}-0.081 \\
(-0.48)\end{array}$ & .54 \\
\hline Charlotte & $\begin{array}{c}0.45 \\
(3.10)\end{array}$ & 0 & $\begin{array}{c}0.67 \\
(3.06)\end{array}$ & 0 & $\begin{array}{l}0.436 \\
(3.16)\end{array}$ & .78 \\
\hline Chicago & $\begin{array}{c}0.12 \\
(0.99)\end{array}$ & -4 & $\begin{array}{c}0.93 \\
(5.07)\end{array}$ & 0 & $\begin{array}{l}0.247 \\
(2.59)\end{array}$ & .66 \\
\hline Cincinnati & $\begin{array}{c}0.65 \\
(5.87)\end{array}$ & -1 & $\begin{array}{c}0.92 \\
(5.08)\end{array}$ & 0 & $\begin{array}{l}0.062 \\
(0.73)\end{array}$ & .67 \\
\hline Cleveland & $\begin{array}{c}0.61 \\
(5.03)\end{array}$ & 0 & $\begin{array}{c}1.29 \\
(6.77)\end{array}$ & 0 & $\begin{array}{r}-0.043 \\
(-0.43)\end{array}$ & .71 \\
\hline Columbus (OH) & $\begin{array}{c}0.65 \\
(5.25)\end{array}$ & 0 & $\begin{array}{c}0.58 \\
(2.98)\end{array}$ & 0 & $\begin{array}{l}0.221 \\
(2.19)\end{array}$ & .68 \\
\hline Dallas & $\begin{array}{c}0.57 \\
(5.55)\end{array}$ & 0 & $\begin{array}{c}0.18 \\
(1.20)\end{array}$ & 1 & $\begin{array}{l}0.383 \\
(3.11)\end{array}$ & .83 \\
\hline Dayton & $\begin{array}{c}0.92 \\
(4.37)\end{array}$ & 0 & $\begin{array}{c}1.73 \\
(5.37)\end{array}$ & 0 & $\begin{array}{r}-0.098 \\
(0.54)\end{array}$ & .66 \\
\hline Denver & $\begin{array}{c}0.40 \\
(3.07)\end{array}$ & 4 & $\begin{array}{c}0.28 \\
(1.39)\end{array}$ & -1 & $\begin{array}{l}0.477 \\
(2.93)\end{array}$ & .73 \\
\hline Detroit & $\begin{array}{c}0.99 \\
(4.05)\end{array}$ & 0 & $\begin{array}{c}1.66 \\
(4.29)\end{array}$ & -1 & $\begin{array}{l}0.012 \\
(0.06)\end{array}$ & .63 \\
\hline Flint & $\begin{array}{c}4.65 \\
(3.94)\end{array}$ & 0 & $\begin{array}{c}6.28 \\
(3.32)\end{array}$ & 0 & $\begin{array}{l}-2.060 \\
(-2.18)\end{array}$ & .39 \\
\hline Greensboro & $\begin{array}{c}0.58 \\
(4.59)\end{array}$ & 0 & $\begin{array}{c}0.97 \\
(4.86)\end{array}$ & 0 & $\begin{array}{l}0.268 \\
(2.55)\end{array}$ & .74 \\
\hline Hartford & $\begin{array}{c}0.54 \\
(4.23)\end{array}$ & -1 & $\begin{array}{c}-0.14 \\
(-0.67)\end{array}$ & 6 & $\begin{array}{l}0.130 \\
(1.32)\end{array}$ & .55 \\
\hline Houston & $\begin{array}{c}0.10 \\
(0.76)\end{array}$ & -4 & $\begin{array}{c}0.44 \\
(2.42)\end{array}$ & 0 & $\begin{array}{l}0.105 \\
(0.56)\end{array}$ & .81 \\
\hline Indianapolis & $\begin{array}{c}0.75 \\
(5.47)\end{array}$ & 0 & $\begin{array}{c}1.18 \\
(5.38)\end{array}$ & 0 & $\begin{array}{r}0.095 \\
(0.085)\end{array}$ & .70 \\
\hline Jacksonville & $\begin{array}{c}0.76 \\
(4.52)\end{array}$ & 0 & $\begin{array}{c}0.36 \\
(1.36)\end{array}$ & 0 & $\begin{array}{l}0.189 \\
(1.41)\end{array}$ & .45 \\
\hline
\end{tabular}




$\begin{array}{lc}\text { Kansas City } & 0.65 \\ & (4.60) \\ \text { Los Angeles } & 0.49 \\ & (4.21) \\ \text { Louisville } & 0.56 \\ & (3.10) \\ \text { Memphis } & 0.47 \\ & (3.21) \\ \text { Miami } & 0.68 \\ & (3.97) \\ \text { Milwaukee } & 0.46 \\ & (3.11) \\ \text { Minneapolis } & 0.69 \\ & (5.17) \\ \text { Nassau-Suffolk } & 0.72 \\ & 16.22) \\ \text { New Orleans } & 0.48 \\ & (2.95) \\ \text { New York } & 0.33 \\ & (2.71) \\ \text { Newark } & 0.49 \\ & (4.95) \\ \text { Norfolk } & 0.67 \\ & (4.59) \\ \text { Omaha } & 0.59 \\ & (4.21) \\ \text { Orlando } & 0.67 \\ & (2.45) \\ \text { Philadelphia } & 0.40 \\ & (3.93) \\ \text { Phoenix } & 0.65 \\ & (3.74) \\ \text { Pittsburgh } & 0.48 \\ & (2.90) \\ \text { Portland (OR) } & 0.45 \\ & (2.64) \\ \text { Raleigh-Durham } & 0.73 \\ \text { Rochester } & (4.03) \\ \text { St. Louis } & 0.33 \\ \text { San Antonio } & (2.58) \\ & 0.64 \\ \text { San Diego } & (4.12) \\ & 0.47 \\ \text { San Francisco } & (3.90) \\ \text { San Jose } & 0.80 \\ \text { Tulsa } & (4.30) \\ \text { Youngstown } & 0.47 \\ & (3.74) \\ & 0.32 \\ & (1.65) \\ & 0.71 \\ & (3.78) \\ 0.97 \\ (2.63) \\ \end{array}$

\begin{tabular}{|c|c|c|c|c|}
\hline 0 & $\begin{array}{c}0.88 \\
(3.75)\end{array}$ & 1 & $\begin{array}{l}0.102 \\
(0.93)\end{array}$ & .59 \\
\hline 0 & $\begin{array}{c}0.62 \\
(3.62)\end{array}$ & 0 & $\begin{array}{l}0.229 \\
(2.07)\end{array}$ & .79 \\
\hline 1 & $\begin{array}{c}1.65 \\
(5.26)\end{array}$ & 0 & $\begin{array}{l}0.120 \\
(0.85)\end{array}$ & .55 \\
\hline 6 & $\begin{array}{c}1.02 \\
(4.01)\end{array}$ & 0 & $\begin{array}{l}0.317 \\
(2.26)\end{array}$ & .69 \\
\hline 0 & $\begin{array}{c}0.27 \\
(1.01)\end{array}$ & 1 & $\begin{array}{l}0.390 \\
(2.57)\end{array}$ & .69 \\
\hline 0 & $\begin{array}{c}1.09 \\
(4.77)\end{array}$ & 0 & $\begin{array}{l}0.205 \\
(1.69)\end{array}$ & .69 \\
\hline 0 & $\begin{array}{c}0.53 \\
(2.56)\end{array}$ & 0 & $\begin{array}{l}0.273 \\
(2.41)\end{array}$ & .72 \\
\hline 0 & $\begin{array}{c}0.28 \\
(1.58)\end{array}$ & 0 & $\begin{array}{l}0.082 \\
(0.86)\end{array}$ & .59 \\
\hline 2 & $\begin{array}{l}-0.46 \\
(-1.66)\end{array}$ & -5 & $\begin{array}{l}0.123 \\
(0.93)\end{array}$ & .46 \\
\hline 0 & $\begin{array}{c}0.26 \\
(1.45)\end{array}$ & 0 & $\begin{array}{l}-0.071 \\
(-0.59)\end{array}$ & .55 \\
\hline 0 & $\begin{array}{c}0.52 \\
(3.05)\end{array}$ & -4 & $\begin{array}{l}0.119 \\
(1.59)\end{array}$ & .56 \\
\hline 0 & $\begin{array}{c}0.34 \\
(1.49)\end{array}$ & 1 & $\begin{array}{c}0.217 \\
(1.84)\end{array}$ & .56 \\
\hline-2 & $\begin{array}{c}0.55 \\
(2.44)\end{array}$ & 1 & $\begin{array}{l}0.234 \\
(2.17)\end{array}$ & .58 \\
\hline 0 & $\begin{array}{c}0.21 \\
(0.51)\end{array}$ & 3 & $\begin{array}{l}0.690 \\
(2.17)\end{array}$ & .76 \\
\hline 0 & $\begin{array}{c}0.42 \\
(2.52)\end{array}$ & 0 & $\begin{array}{l}0.087 \\
(1.12)\end{array}$ & .50 \\
\hline 0 & $\begin{array}{c}-0.64 \\
(-0.25)\end{array}$ & 2 & $\begin{array}{l}0.815 \\
(4.16)\end{array}$ & .82 \\
\hline 0 & $\begin{array}{c}0.64 \\
(2.56)\end{array}$ & -1 & $\begin{array}{l}0.022 \\
(0.15)\end{array}$ & .60 \\
\hline-1 & $\begin{array}{c}0.84 \\
(3.27)\end{array}$ & 0 & $\begin{array}{l}0.371 \\
(2.35)\end{array}$ & .72 \\
\hline-3 & $\begin{array}{r}0.72 \\
(2.70)\end{array}$ & 0 & $\begin{array}{l}0.327 \\
(2.07)\end{array}$ & .58 \\
\hline-6 & $\begin{array}{c}1.16 \\
(5.83)\end{array}$ & 0 & & .64 \\
\hline 0 & $\begin{array}{c}1.13 \\
(4.57)\end{array}$ & 0 & $\begin{array}{r}-0.063 \\
(0.51)\end{array}$ & .57 \\
\hline 0 & $\begin{array}{c}0.57 \\
(3.31)\end{array}$ & 0 & $\begin{array}{l}0.313 \\
(2.30)\end{array}$ & .65 \\
\hline 0 & $\begin{array}{c}0.47 \\
(1.71)\end{array}$ & 0 & $\begin{array}{c}0.188 \\
(1.06)\end{array}$ & .60 \\
\hline-6 & $\begin{array}{c}0.63 \\
(3.24)\end{array}$ & 0 & $\begin{array}{l}0.028 \\
(0.26)\end{array}$ & .59 \\
\hline-6 & $\begin{array}{c}0.55 \\
(2.00)\end{array}$ & 0 & $\begin{array}{l}0.589 \\
(2.79)\end{array}$ & .73 \\
\hline-6 & $\begin{array}{c}0.43 \\
(1.56)\end{array}$ & 1 & $\begin{array}{l}0.221 \\
(1.22)\end{array}$ & 62 \\
\hline 0 & $\begin{array}{c}3.56 \\
(5.89)\end{array}$ & 0 & $\begin{array}{r}-0.133 \\
(0.46)\end{array}$ & .48 \\
\hline
\end{tabular}

\section{FOOTNOTES}

'The 50 U.S. metropolitan regions in the sample are: Albany, NY Anaheim, CA Atlanta, GA Austin, TX Flint, MI Greensboro, NC Omaha, NE Hartford, CT Orlando, FL Houston, TX Philadelphia, PA Baltimore, MD Indianapolis, IN Phoenix, AZ Binningtham AL Jacksonville, FL Pittsburgh, PA Boston, MA Kansas City, KS Portland, OR Buffalo, NY Los Angelen CA RaleighDurham, NC
Charlotte, NC Louisville, KY Rochester, NY Chicago, IL Memphis, TN St. Louis, MO Cincinnati, OH Miami, FL San Antonio, TX Cleveland, OH Milwaukee, WI San Diego, CA Columbus, OH Minneapolis, MN San Prancisco, CA Dallas, TX Nassau- San Jose, CA Dayton, OH Suffolk, NY Tulsa, OK Denver, CO New Orleans, LA Youngstown, OH Detroit, MI New York, NY Newark, NJ

These regions include the largest 25 metropolitan areas in the United States (as measured by 1980 total nonegricultural employment) with the exception of Seattle (data 
not available). Most of the next 25 largest metropolitan areas are included. Exceptions were made to ensure locational balance and diversity of areas by industry composition, and non-overpresentation of state capitals. Also some areas were included whose economies were known to be undergoing substantial structural change. Those of the 50 largest areas not included and their rank by size (besides Seattle, "20) are Washington, D.C. SMSA (27); Tampa-St. Petersburg, FL (30); Riverside, CA (35); Providence, RI (37); Oklahoma City, OK (38); Sacramento, CA (39); Salt Lake City, UT (43); Nashville, TN (45); and Ft. Lauderdale-Hollywood, FL (49). Included but not among the 50 largest areas are: Charlotte, NC (51); Tulsa, OK (54); Jacksonville, FL (55); Orlando, FL (58); Norfolk, VA (59); Raleigh-Durham, NC (60); Omaha, NE (64); Austin, TX (68); Youngstown- Warren, $\mathrm{OH}$ (78); and Flint, MI (83).

${ }^{2}$ The 1980-83 period had two recessions as measured by national total nonagricultural employment fluctuations, and by the National Bureau of Economic Research. The latter recession is based upon two successive quarters of negative growth in GNP. There was a short recession in 1980 followed immediately by one in 1981 which lasted through 1982. For purposes of this analysis we have combined these two recessions by measuring from the highest level of employment in $1979,1980,1981$, or 1982 to the lowest employment level after the respective regional peak up until November 1983.

'Analyses were not performed on more detailed industry sectors because of the lack of time-series data over the full period for a large number of regions. The FIRE sector is the one SIC major industry group in closest conformity to what Noyelle and Stanback (1983) call the advanced services.

'Of course the regional concentration of FIRE employment can increase merely by net losses in other sectors. This may partially account for the lack of statistical significance in the correlation coefficient.

'The monthly time-series data for the index of production in OECD countries were obtained from the CITIBASE data file of national and international economic variables. This series was already seasonally-adjusted.

See Pindyck and Rubinfeld (1981, pp. 238-239), for the derivation of the estimated form of the polynomial distributed lag model. In this analysis a third-degree polynomial was used to approximate the lag structure. A 13 period lead-lag structure (up to six months lead, contemporaneous, and up to six months lag) was chosen, and no endpoint restrictions were placed on the lag weights. These choices were made to maximize flexibility of the model since no theories were available to provide $a$ priori specification of the lag structure.

TThe data preparation and calibration procedure was as follows: 1) all monthly total employment time-series data for the metropolitan regions and the United States were seasonally adjusted; 2) values of $m$ and $n$ were selected for each region, after adjusting for first, second, and third-order serial correlation (using the SAS autoreg procedure in regression models similar to (1) but without IPE an an independent variable); 3) equation (1) was calibrated using the Time Series Processor (TSP) polynomial distributed-lag regression estimation procedure. This procedure uses the Cochrane-Orcutt transformation to remove first-order serial correlation.

'In principle it is possible to measure this portion of the effect of international economic fluctuations on regional economies through the national economy with either a recursive or simultaneous equation model formulation. This extension is mentioned briefly in the last section of the paper.

'See Bergman and Goldstein (1983) for an analysis of differences in the sensitivity of U.S. metropolitan regions to national economic expansions and contractions. The asymmetry of a given region's sensitivity to national ex- pansions and contractions leads to what Bergman and Goldstein have called the cyclical ratchet. The latter represents a conceptual link between uneven regional cyclical behavior and divergent regional secular growth trends.

${ }^{10} \mathrm{The}$ complete set of calibration results, including the coefficient estimates for each individual lead or lag period, can be obtained on request from the author.

\section{REFERENCES}

Bergman, Edward M. and Harvey A. Goldstein. Dynamics and Structural Change in Metropolitan Economies. Journal of the American Planning Association, 1983. 49, 3: 263-279.

Bluestone, Barry and Bennett Harrison. The Deindustrialization of America. New York: Basic Books, 1982.

Borts, George. Regional Cycles of Manufacturing Employment in the United States, 1914-1953, Journal of the American Statistical Association, 1960, 55: 151-211.

Browne, Lynn. Regional Industry Mix and the Business Cycle. New England Economic Review Nov./Dec. 1978: 35-53.

Cohen, Robert. The New International Division of Labor, Multinational Corporations and Urban Hierachy. In Urbanization and Urban Planning in a Capitalist Society, eds. M. Dean and A. J. Scott. London: Methuen and Co. Ltd., 1981.

Conroy, Michael. The Challenge of Urban Economic Development. Lexington, Mass: D.C. Heath, 1975.

Glickman, Norman J. International Trade, Capital Mobility, and Economic Growth: Some Implications for American Cities in the 1980s. Report to the President's Commission for a National Agenda for the Eighties. Working Paper 32, University of Pennsylvania, Department of Regional Science, 1980.

Glickman, Norman J. Economic Policy and the Cities: In Search of Reagan's "Real Urban Policy." Journal of the American Planning Association, 1984, 50: 471-478.

Glickman, Norman J. Cities and the International Division of Labor. Working paper No. 31, L.B.J. School of Public Affairs, University of Texas at Austin, 1985

Glickman, Norman J. and Marcia Van Wagner. Two Cheers for Industrial Policy: A Critical Look at Some Urban and Distributional Issues. Working Paper No. 32, L.B.J. School of Public Affairs, University of Texas at Austin, 1984.

Hansen, Niles. The New International Division of Labor and Manufacturing Decentralization in the United States. The Review of Regional Studies. 1979, 9: 1-11.

Howland, Marie. Age of Capital and Regional Business Cycles. Growth and Change, April 1984: 29-37.

Kort, John R. Regional Economic Instability and Industrial Diversification in the U.S. Land Economics. 1981, 54,4: 596-608.

King, Leslie J. et al. Spatial-Temporal Patterns in Employment Growth. Growth and Change 3, 1: 37-42, 1972.

Luger, Michael I. Federal Tax Incentives as Industrial and Urban Policy. Sunbelt-Frostbelt: Regional Change and Industrial Restructuring. W. Tabb and L. Lawers (eds.). New York: Oxford University Press, 1983.

Magaziner, Ira. C. and Robert B. Reich. Minding America's Business, New York: Vintage books, 1982.

Muller, Ronald E. Revitalizing America: Politics for Prosperity. New York: Simon and Schuster, 1980.

Noyelle, Thierry J. The Implications of Industry Restructuring for Spatial Organization in the United 
States. Regional Analysis and the New International Division of Labor. Frank Moulaert and Patricia Salinas (eds). Boston: Kluwer-Nijhoff Publishing, 1982.

Noyelle, Thierry J. and Thomas Stanback. The Economic Transformation of American Cities. Totowa, NJ: Rowman and Allanheld, 1983.

Pindyck, Robert S. and Daniel L. Rubinfeld. Econometric Models and Economic Forecasts, second edition. New York: McGraw-Hill, 1981.

Renaud, Bertrand. Structural Changes in Advanced Economies and Their Impact on Cities in the 1980s. Research in Urban Economics, 4: 1-10, 1984.

Thompson, Wilbur. A Preface to Urban Economics. Baltimore: The Johns Hopkins Press, 1965.

U.S. Department of Commerce, Bureau of the Census.
Annual Survey of Manufacturers. Washington, D.C.: U.S. Government Printing Office, 1981.

U.S. Department of Housing and Urban Development. The Impact of Foreign Direct Investment on U.S. Cities and Regions. Washington, D.C., 1979.

U.S. Department of Labor, Bureau of Labor Statistics. Employment and Earnings (monthly).

Vernez, Georges et al. Regional Cycles and Employment Effects of Public Works Investments. Santa Monica, CA.: The Rand Corporation, R-2052-EDA, 1977.

Victor, Richard B. and Georges Vernez. Employment Cycles in Local Labor Markets. Santa Monica, CA.: The Rand Corporation, R-2647-EDA/RC, 1981.

Vining, R. Location of Industry and Regional Patterns of Business Cycle Behavior. Econometrica, 1946: 14, 37-68. 